INTERNATIONAL JOURNAL OF RESEARCHES IN BIOSCIENCES, AGRICULTURE AND TECHNOLOGY (c) VISHWASHANTI MULTIPURPOSE SOCIETY (Global Peace Multipurpose Society) R. No. MH-659/13(N) www.ijrbat.in

\title{
POST-HARVEST OPERATIONS INFLUENCES SEED QUALITY OF FORAGE CLUSTER BEAN.
}

\author{
Rajesh Gadewar 1, Vipin Babhulkar2, Prachi Lambat 3, , Atul Banginwar4 \\ ${ }^{1}$ Associate Professor, Sevadal Mahila Mahavidyalaya and Research Academy, Nagpur (MS) \\ 2 Assistant Professor, College of Agriculture (Dr. PDKV's) Gadchiroli. \\ ${ }^{3}$ Assistant Professor, D.R.B. Sindhu Mahavidyalaya, Nagpur \\ ${ }^{4}$ Assistant Professor, College of Agriculture (Dr. PDKV's) Nagpur.
}

\begin{abstract}
:
Effects of Threshing, drying and storage methods on seed quality of forage cluster bean were studied. The seeds threshed by hand had maintained significantly very low mechanical damage to seeds and higher germination, seedling vigour and field emergence percentage. Drying of forage cluster bean seeds at lower temperature (shade) recorded significantly higher germination, seedling vigour and field emergence percentage. The forage cluster bean seeds stored in polyethylene bags recorded significantly higher germination, seedling vigour and field emergence and lesser seed invasion by fungal flora during storage as compared to jute and cloth bags under ambient condition. It was also noted that Altrnaria sp., Aspergillus sp., Fusarium sp., Rhizopus sp., Tricothecium sp. And Penicillium sp. Were the most commonly occurring fungi irrespective of storage periods and storage containers during storage under ambient condition.

Keywords: forage cluster bean, seed quality, threshing, drying, container, storage.
\end{abstract}

\section{INTRODUCTION:}

Forage cluster bean is a rich source of protein but it is yet to gain impetus in our country. One of the major problems encountered in forage cluster bean production in India is the lack of good quality seeds. Seed yield and its quality depend on a number of factors. The time of harvesting, methods of threshing, drying and storage of seeds are among the major consideration in deciding the seed quality and productivity. Seed quality may be impaired while the seeds are still on mother plant (Pullock, 1972) Physiomorphological and physiological changes might set in, if the seeds are retained on the mother plant for a longer duration beyond physiological maturity (Ovchrov and Kizilova, 1966). Dharmalingam and Basu (1988) reported that the seed harvested at physiological maturity had highest germination and vigour than those harvested at premature. Sangakkara and Wanisekera (1990) reported that the mungbean seed quality not affected by hand threshing, drying at low temperature and storing the seeds in polyethylene bags in low temperature and relative humidity. As very little information is available on this aspect, hence an experiment was planned to study the effect of post harvest operations on seed quality of forage cluster bean

\section{MATERIAL METHODS:}

Plants of forage cluster bean (Variety Pusa Navbahar) were harvested at physiological maturity (i.e. when green pod turns in blackish green in colour). Pods were removed from the harvested plants and dried on the threshing floor as per usual method of drying. The harvested pods were divided in to 5 lots. First lot was threshed by hand, $2^{\text {nd }}$ by stick beating $3^{\text {rd }}$ by machine threshed $300 \mathrm{rpm}$. $4^{\text {th }}$ by $400 \mathrm{rpm}$ and $5^{\text {th }}$ by $500 \mathrm{rpm}$ separately. Half threshed seeds of each threshing methods dried in the sun and remaining half threshed seed was dried in the sun and remaining half threshed seed was dried in shade. Three days were required for sun drying and 10 days were required for shade drying to reach safe moisture content level $(10 \pm 1 \%)$. The threshed and dried seeds by different methods were 
kept in jute, cloth and polyethylene bags of size $20 \mathrm{~cm} \times 30 \mathrm{~cm}$ respectively of $1 \mathrm{Kg}$ each and stored in wire - mesh almirah in masonry building having cemented wall, roof and floor under ambient condition for 9 months. The observations on moisture content and germination tests was conducted as prescribed in International rules for seed testing (ISTA, 1985). Two hundred seeds were used to isolate fungi following standard blotter and agar plate methods (ISTA,1976). The seedling vigour index was worked out following the method of Aldul Baki \& Anderson (1973). For filed emergence test, sowing of forage cluster bean seeds was done in randomized block design, with four replications with inter and intra-row spacing of 1 feet and 6 inches respectively. Observations for field emergence were recorded daily and finally the established seedlings were counted after one month of sowing. The experimental data was statistically scrutinized by random bloc design as per Panse and Sukhatme (1967).

\section{RESULT \& DISCUSSION :}

Data presented in the Table 1 showed that machine threshed at $500 \mathrm{rpm}$ results into seeds with significantly maximum mechanical damage $(3.2 \%)$ which is followed by $400 \mathrm{rpm}(2.6 \%) 300 \mathrm{rpm}$ $(1.6 \%)$, stick beating $(1.4 \%)$, and hand threshed (0.3\%). Saini et al. (1982), Sangakkara and Wanisekera (1990) reported that the seed threshed by hand lower mechanical damage to seed coat than machine threshed.

In was observed form the Table 1 that the germination percentage of forage cluster bean seeds threshed by different methods varies significantly and it was highest in hand - threshed seeds (95\%) which was closely followed by stick-beating (91\%), machine threshed $300 \mathrm{rpm}$ (84\%), $400 \mathrm{rpm} \mathrm{(80 \% )}$ and $500 \mathrm{rpm}(71 \%)$. The germination percentage was decreased with increasing in mechanical damage to the seed coat of forage cluster bean. It was also observed that the abnormal seedling increases with the increasing the mechanical damage to the seed coat of forage cluster bean. The similar results also reported by Soesarsano and Copeland (1974), Sangakkara, Waniseker (1990), and Lambat et al. (2011) Seedling vigour index and filed emergence followed the same trends of germination. It was highest in hand- threshed seeds as compared to other threshing method.

The effect of seed drying methods for reduction the moisture content to a desirable level is presented in Table 2. The result suggested that the three (3) days were required for sun drying and ten (10) days required for shade drying to reach safe level of moisture content $(10+1 \%)$. Study on seed drying indicated that the germination of sundried hand threshed seeds was $(87 \%)$ which is closely followed by stick beating $(83 \%)$, machine-threshed $300 \mathrm{rpm}$ (80\%), $400 \mathrm{rpm}(78 \%)$ and $500 \mathrm{rpm} \mathrm{(70 \% ).} \mathrm{As}$ against $95 \%$ in hand- threshed, 90\% in stick beating, $85 \%$ in machine-threshed $300 \mathrm{rpm} 85 \%$ in $400 \mathrm{rpm}$ and $78 \%$ in $500 \mathrm{rpm}$ in shade dried seeds. In shade drying, low temperature minimizes scorching due to gradual loss of the moisture and there was no adverse effect on germinability of seeds. The result confirms the findings of Philpot, (1976), Patil and Zode, (1993), Lambat et al. (2011). In sun drying, high ambient temperature develop a rapid flow of moisture within the seeds causing stress and sun scorching to the embryo and cotyledons and this results in reduction of germinability with high number of abnormal seedlings and dead seeds. Morrison and Robertson, (1978), Sangakkara and Wanisekera, (1990), Patil and Zode, (1993). Seedling vigour index and field emergence percentage also followed the same trend of germination in seed. Similar results also reported by Saini et al. (1982) Patil and Zode, (1993) and Lambat et al. 2011 
The apparent influence of threshing, drying methods and storage containers on germination, seedling vigour index and field emergence percentage of seeds during storage presented in Table 3. The data indicated that the germination, seedling vigour and field emergence percentage of stored seed declined with increasing storage period, however the rate of loss varied with the methods of threshing, drying and types of storage containers used. A sharp declined in germination, seedling vigour index and field emergence occurred in seeds threshed by machine $500 \mathrm{rpm}$, drying in sun and stored in jute, cloth and polyethylene bags during storage. However, there was practically less loss of germination, seedling vigour index and field emergence percentage in seeds threshed by hand dried in shade and stored in jute, cloth and polyethylene bags during storage for 9 months Sangakkara and Wanisekera, (1990), Patil and Zode, (1993) and Lambat et al. (2011) also reported that the sun drying of seeds harmful for germination. In the present study, it was observed that the seed, stored in polyethylene bags were undergo the least amount of loss of germinability to great extent as compared to jute and cloth bags irrespective to threshing and drying method Vanangamudi, (1988), Shivankar et al. (1990), Likhitkar and Charjan, (1995) and Lambat et al. (2011) also reported superiority of polyethylene bags over jute and cloth bags for successful carry over of seed during storage. In the present study, the similar trends of germination were observed in seedling vigour index and field emergence percentage of forage cluster bean seeds during storage.

During this study (Table 4) it was evident that the maximum number of fungal colonies did develops in jute bags which are followed by cloth bags and polytheylene bags during storage. The polyethylene bags provided much protection as polyethylene bags resist moisture penetration which helps in preventing the development of fungal colonies both quantitative and species wise irrespective eto threshing and drying methods. It was also noted that Alternaria sp., Aspergillus sp. Fusarium sp., Penicillium sp., Rhizopus sp. and Trichothecium sp. were the most commonly occurring fungi irrespective of storage periods and containers. The germinability of seeds decreased with increase in incidence percentage of fungal flora and storage period. The isolated fungi were most inhibitory to germination. The result obtained were in conformity with the findings of Charjan and Gupta (1996) \& Wankhede et al. (2010) and Lambat et al. (2011). It was also observed that the lower storage potential of mechanical damage seeds threshed by machine and sun dried may be because of higher rate of respiration and attraction of more fungal flora due to higher leaching of sugar which cause early reduction in germination, seedling vigour and field emergence (Burriga, 1961 and Lambat et al 2011)

\section{CONCLUSION.}

Thus, these results highlight the maintenance of forage cluster bean seed quality of sowing purposes in the next sowing reason for getting better yield. The forage cluster bean pods should be threshed by hand or stick beating and dried in shade upto safe moisture level $(10 \pm 1 \%)$ and stored in polyethylene bags, shows greater germinability, seedling vigour index and filed emergence and lesser invasion by fungal flora upto the next sowing season.

\section{REFERANCE :}

Abdul Baki A. and J.D. Anderson. 1973. Vigour determination in soybean seed by multiple criteria. Crop Sci. 13: 630-633.

Barriga, C. 1961. Effect of mechanical abuse of navybean seed at various moisture levels. Agron J. 63 : 250-250.

Charjan, S.K.U. and V.R. Gupta 1996. Impact of storage condition on fungal flora and germinability of gram seeds. J. Soils and crops 6 (2) : 136-138.

Dharmalingam, C. and R.N. Basu. 1988. Seed quality in relation to position of seed in the pod at different maturity periods in mungean. Seed Res. 16(2) : 168-172. 
ISTA. 1976. International rules for seed testing seed sci. and technol 4: 108

ISTA. 1985. International rules ofr seed testing seed sci. and Technol $13: 299-513$

Lambat, A. Gadewar, R., Charde, P. Charjan, S., Cherian, K. and Lambat, P. 2011. Effect of Post harvest operations on seed quality of mung (Phaseolus mungo L.) In : Proc. International Conference in Agricultural Engineering, Chonburi, Thailand page No. C/13-25

Likhitkar, V.S. and S.K.U. Charjan, 1995. Impact of storage containers and period on germination of Gimelina arborea seeds during storage. In : Herbal medicines, biodiversity and conservation strategies (Ed. R.C. Rajak and M.K.Rai), international book distributors, Distributors, Deharadun : 236-241.

Morrison, W.H. III and J. A. Robertson. 1978. Effect of drying on sunflower seed oil quality and germination. J. Am oil chem.. Soc. 55 : 272274.

Ovcharov, K.E. and K.G. Kizilova 1966. Difference in seed quality and plant productivity. In: Physiological basis of seed germination. Amerinol publishing, New Delhi pp. 140.

Panse V.G. and P.V. Sukhatme. 1967. Statistical methods for agril. Workers I.C.A.R. Publication New Delhi.

Patil, V.N. and N.G. Zode. 1993. Effect of seasons and drying methods on storability of ground nut (arachis hypogaea) Seed res. Special Vol. 1: 342-247.

Philpot, R. 1976. Principles and practices of seed drying. Proceeding of Mississipi state University Short course for seedmen $16: 23-$ 40.

Pullock, B.M. 1972. Effects of environment after sowing on viability. In: Viability of seeds (ed. E.H. Roberts), Chapman and hall Ltd. Landon pp. 150-171.

Saini, S.K., J.N. Singh and P.C. Gupta. 1982. Effect of threshing method on seed quality of soybean. Seed Res. 10 (2): 133-138.

Sangakkara, U.R. and W.M.T. Wanisera. 1990. Effect of post-harvest operations on seed quality of mungbean. Seed Res. 18(1) : 54-59.

Shivankar, V.J., S.N. Singh, A.A. Khan and A.S. Tomer. 1990. Effect of storage conditions on storability of cowpea. In International conference on seed science and technology, New Delhi.

Soesarsano, W. and I.C. Copeland. 1974. Effect of original moisture content, maturity and mechincal damage on seed and seedling vigour of beans. Agron J. 66: 546-548.

Vanangammudi, K. 1988. Storability of soybean seeds as influenced by the variety, seed size and storage container. Seed Res. 16(1) : 8187.

\begin{tabular}{|c|c|c|c|c|c|c|c|c|}
\hline \multirow{2}{*}{$\begin{array}{l}\text { Sr. } \\
\text { No. }\end{array}$} & \multirow{2}{*}{$\begin{array}{l}\text { Threshing } \\
\text { methods }\end{array}$} & \multirow{2}{*}{$\begin{array}{c}\text { Mechanically } \\
\text { damaged } \\
\text { seed }(\%)\end{array}$} & \multirow{2}{*}{$\begin{array}{l}\text { Sound } \\
\text { seed } \\
(\%)\end{array}$} & \multicolumn{3}{|c|}{ Germination Analysis \% } & \multirow{2}{*}{$\begin{array}{l}\text { Seedling } \\
\text { Vigour } \\
\text { Index }\end{array}$} & \multirow{2}{*}{$\begin{array}{c}\text { Field } \\
\text { emergence } \\
(\%)\end{array}$} \\
\hline & & & & $\begin{array}{c}\text { Normal } \\
\text { seedling } \\
(\%)\end{array}$ & $\begin{array}{c}\text { Abnormal } \\
\text { Seedling } \\
(\%)\end{array}$ & $\begin{array}{c}\text { Dead } \\
\text { Seed } \\
(\%)\end{array}$ & & \\
\hline 1 & $\begin{array}{c}\text { Hand - } \\
\text { Threshing }\end{array}$ & 0.2 & 99.8 & 96 & 2 & 2 & 1209 & 88 \\
\hline 2 & Stick Beating & 103 & 98.6 & 91 & 5 & 4 & 1101 & 82 \\
\hline 3 & $\begin{array}{c}\text { Machine- } \\
\text { Threshing } 300 \\
\text { rpm }\end{array}$ & 1.6 & 98.4 & 84 & 12 & 6 & 1090 & 74 \\
\hline 4 & $400 \mathrm{rpm}$ & 2.6 & 97.4 & 80 & 15 & 5 & 911 & 69 \\
\hline \multirow[t]{3}{*}{5} & $500 \mathrm{rpm}$ & 3.2 & 96.8 & 71 & 21 & 8 & 808 & 59 \\
\hline & $\mathrm{SE}(\mathrm{m}) \pm$ & 0.2 & 0.2 & 1.5 & $\mathrm{n} / \mathrm{a}$ & $\mathrm{n} / \mathrm{a}$ & 68 & 1.2 \\
\hline & C.D at $5 \%$ & 0.7 & 0.6 & 4.5 & $\mathrm{n} / \mathrm{a}$ & $\mathrm{n} / \mathrm{a}$ & 206 & 3.7 \\
\hline
\end{tabular}


Table 2 : Effect of threshing and drying methods on germination percentage, seedling vigour index and field emergence percentage in Popatwal.

\begin{tabular}{|c|c|c|c|c|c|c|c|c|c|c|c|}
\hline \multirow{3}{*}{$\begin{array}{l}\text { Sr. } \\
\text { No }\end{array}$} & \multirow{3}{*}{$\begin{array}{l}\text { Threshing } \\
\text { Methods }\end{array}$} & \multicolumn{5}{|c|}{ Shade drying } & \multicolumn{5}{|c|}{ Sun drying } \\
\hline & & \multicolumn{5}{|c|}{ G.A. $\%$} & \multicolumn{5}{|c|}{ G.A. $\%$} \\
\hline & & NS & ABS & DS & SVI & FE\% & NS & ABS & DS & SVI & FE\% \\
\hline 1 & $\begin{array}{c}\text { Hand - } \\
\text { Threshing }\end{array}$ & 95 & 3 & 2 & 1139 & 87 & 87 & 6 & 7 & 1099 & 78 \\
\hline 2 & Stick Beating & 90 & 6 & 4 & 1003 & 80 & 83 & 10 & 7 & 1001 & 73 \\
\hline 3 & $\begin{array}{l}\text { Machine- } \\
\text { Threshing } \\
300 \mathrm{rpm}\end{array}$ & 85 & 9 & 4 & 979 & 78 & 80 & 14 & 6 & 7979 & 70 \\
\hline 4 & $400 \mathrm{rpm}$ & 83 & 12 & 3 & 882 & 75 & 78 & 17 & 5 & 912 & 67 \\
\hline 5 & $500 \mathrm{rpm}$ & 78 & 20 & 2 & 814 & 68 & 70 & 19 & 11 & 810 & 58 \\
\hline & $\mathrm{SE}(\mathrm{m}) \pm$ & 1.2 & $\mathrm{~N} / \mathrm{A}$ & $\mathrm{N} / \mathrm{A}$ & 50 & 1.2 & 1.2 & N/A & $\mathrm{N} / \mathrm{A}$ & 55 & 1.3 \\
\hline & C.D at $5 \%$ & 3.7 & $\mathrm{~N} / \mathrm{A}$ & $\mathrm{N} / \mathrm{A}$ & 151 & 3.6 & 3.7 & N/A & $\mathrm{N} / \mathrm{A}$ & 166 & 4.0 \\
\hline
\end{tabular}

(G.A.- Germination analysis, NS-Normal Seedling, ABS- Abnormal seedling, DS-Dead seed, SVI Seedling vigour index, FE-Field emergence. SE $(\mathrm{m}) \pm$ Standard Error mean, C.D. at 5\% Critical Difference at 5\%, Normal Seedling $\%=$ Germination $\%$ )

Table 3. Effect of threshing, drying methods and storage containers on germination percentage, seedling vigour index, field emergence percentage in Popatwal during storage.

\begin{tabular}{|c|c|c|c|c|c|c|c|}
\hline \multirow[t]{2}{*}{$\begin{array}{l}\text { Sr. } \\
\text { No. }\end{array}$} & \multirow[t]{2}{*}{$\begin{array}{c}\text { Drying Methods/ Packing } \\
\text { Methods }\end{array}$} & \multicolumn{2}{|c|}{ Germination \% } & \multicolumn{2}{|c|}{$\begin{array}{c}\text { Seedling Vigour } \\
\text { Index }\end{array}$} & \multicolumn{2}{|c|}{ Field emergence $\%$} \\
\hline & & Initial & 9 Months & Initial & $\begin{array}{c}9 \\
\text { Months }\end{array}$ & Initial & $\begin{array}{c}9 \\
\text { Mont } \\
\text { hs }\end{array}$ \\
\hline \multirow[t]{10}{*}{1} & Hand threshed & & & & & & \\
\hline & 1) Shade drying & & & & & & \\
\hline & i) Jute bag & 95 & 89 & 1139 & 901 & 87 & 79 \\
\hline & ii) Cloth bag & 95 & 91 & 1139 & 931 & 87 & 81 \\
\hline & iii) Polyethylene bag & 95 & 93 & 1076 & 1102 & 87 & 83 \\
\hline & 2) Sun drying & & & & & & \\
\hline & i) Jute bag & 87 & 81 & 1099 & 812 & 78 & 71 \\
\hline & ii) Cloth bag & 87 & 81 & 1099 & 812 & 78 & 71 \\
\hline & iii) Polyethylene bag & 87 & 85 & 1099 & 897 & 78 & 75 \\
\hline & $\mathrm{SE}(\mathrm{m})+$ & $\mathrm{N} / \mathrm{A}$ & 2.5 & $\mathrm{~N} / \mathrm{A}$ & 44 & $\mathrm{~N} / \mathrm{A}$ & 2.4 \\
\hline \multirow[t]{10}{*}{2} & Stick beating & & & & & & \\
\hline & 1) Shade drying & & & & & & \\
\hline & i) Jute bag & 90 & 83 & 1003 & 872 & 80 & 66 \\
\hline & ii) Cloth bag & 90 & 81 & 1003 & 821 & 80 & 68 \\
\hline & iii) Polyethylene bag & 90 & 88 & 1003 & 996 & 80 & 75 \\
\hline & 2) Sun drying & & & & & & \\
\hline & i) Jute bag & 83 & 74 & 1001 & 801 & 78 & 63 \\
\hline & ii) Cloth bag & 83 & 75 & 1001 & 792 & 78 & 64 \\
\hline & iii) Polyethylene bag & 83 & 80 & 1001 & 962 & 78 & 70 \\
\hline & $\mathrm{SE}(\mathrm{m})+$ & $\mathrm{N} / \mathrm{A}$ & 2.9 & $\mathrm{~N} / \mathrm{A}$ & 43 & $\mathrm{~N} / \mathrm{A}$ & 3.0 \\
\hline \multirow[t]{5}{*}{3} & Machine-threshed (300 rpm) & & & & & & \\
\hline & 1) Shade drying & & & & & & \\
\hline & i) Jute bag & 85 & 72 & 979 & 840 & 78 & 61 \\
\hline & ii) Cloth bag & 85 & 74 & 979 & 856 & 78 & 63 \\
\hline & iii) Polyethylene bag & 85 & 81 & 979 & 969 & 78 & 71 \\
\hline
\end{tabular}




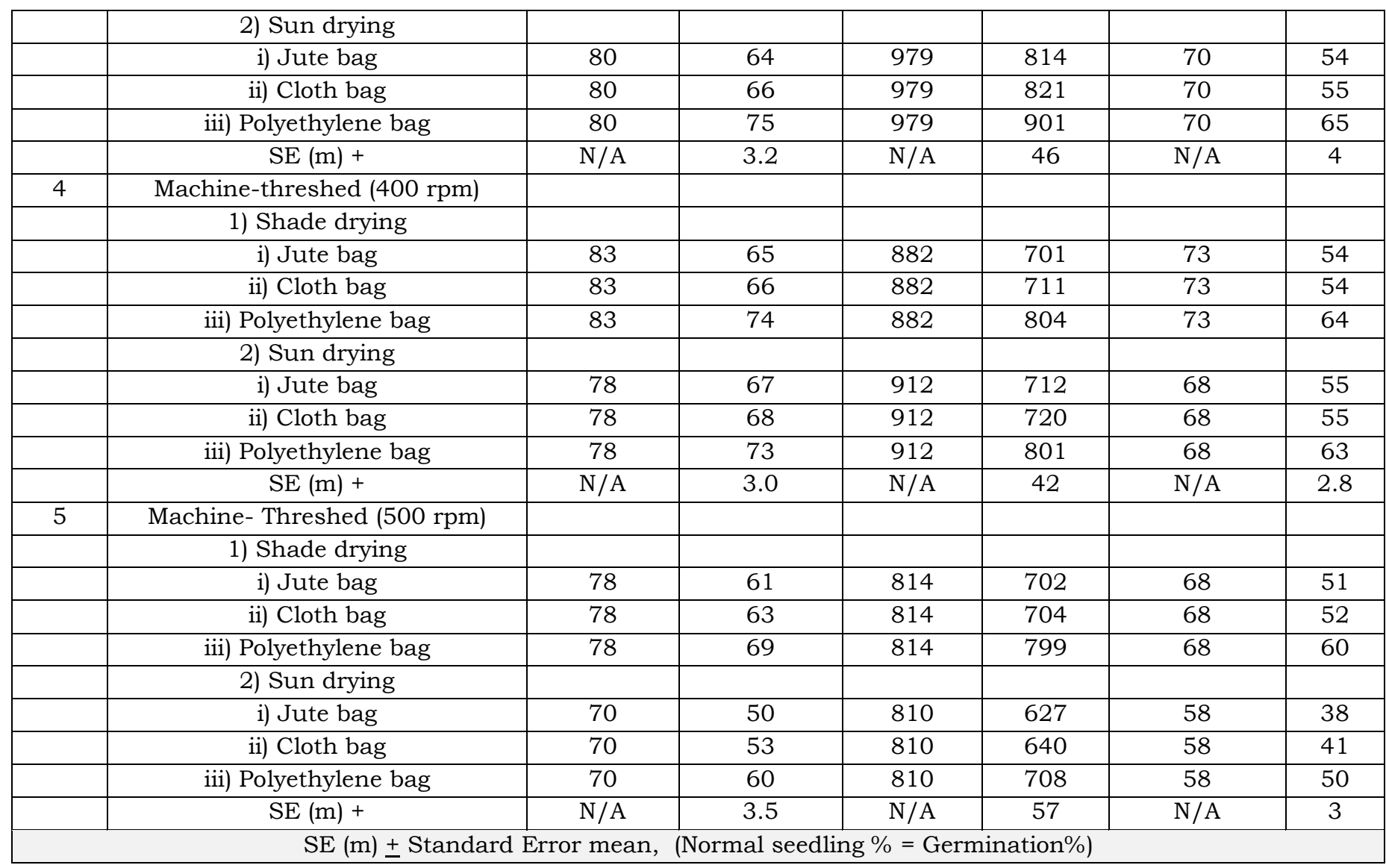

\begin{tabular}{|c|c|c|c|c|c|c|c|c|c|c|c|c|c|}
\hline \multirow{3}{*}{$\begin{array}{l}\text { Sr. } \\
\text { No. }\end{array}$} & \multirow{3}{*}{ Treatments } & \multicolumn{12}{|c|}{ Percentage of fungi encountered on Popatwal seeds } \\
\hline & & $\mathbf{A}$ & & $\mathbf{B}$ & & $\mathbf{C}$ & & $\mathbf{D}$ & & $\mathbf{E}$ & & $\mathbf{F}$ & \\
\hline & & $\mathbf{1}$ & 2 & $\mathbf{1}$ & 2 & $\mathbf{1}$ & 2 & $\mathbf{1}$ & 2 & $\mathbf{1}$ & 2 & $\mathbf{1}$ & 2 \\
\hline \multirow[t]{9}{*}{1} & Hand Threshed & & & & & & & & & & & & \\
\hline & 1) Shade drying & & & & & & & & & & & & \\
\hline & i) Jute bag & 1 & 5 & 3 & 12 & 1 & 5 & 1 & 18 & $\mathrm{~N} / \mathrm{A}$ & 4 & $\mathrm{~N} / \mathrm{A}$ & 1 \\
\hline & ii) Cloth bag & 1 & 4 & 3 & 10 & 1 & 5 & 1 & 22 & $\mathrm{~N} / \mathrm{A}$ & 5 & $\mathrm{~N} / \mathrm{A}$ & $\mathrm{N} / \mathrm{A}$ \\
\hline & iii) Polythylene bag & - & 1 & 2 & 5 & 1 & 1 & 1 & 3 & $\mathrm{~N} / \mathrm{A}$ & 2 & $\mathrm{~N} / \mathrm{A}$ & $\mathrm{N} / \mathrm{A}$ \\
\hline & 2) Sun Drying & & & & & & & & & & & & \\
\hline & i) Jute bag & 1 & 5 & 2 & 15 & $\mathrm{~N} / \mathrm{A}$ & 7 & $\mathrm{~N} / \mathrm{A}$ & 10 & $\mathrm{~N} / \mathrm{A}$ & 5 & $\mathrm{~N} / \mathrm{A}$ & 1 \\
\hline & ii) Cloth bag & 1 & 5 & 2 & 16 & $\mathrm{~N} / \mathrm{A}$ & 8 & $\mathrm{~N} / \mathrm{A}$ & 16 & $\mathrm{~N} / \mathrm{A}$ & 5 & $\mathrm{~N} / \mathrm{A}$ & 1 \\
\hline & iii) Polythylene bag & 1 & 3 & 2 & 7 & $\mathrm{~N} / \mathrm{A}$ & 1 & $\mathrm{~N} / \mathrm{A}$ & 12 & $\mathrm{~N} / \mathrm{A}$ & 2 & $\mathrm{~N} / \mathrm{A}$ & $\mathrm{N} / \mathrm{A}$ \\
\hline \multirow[t]{9}{*}{2} & Stick beating & & & & & & & & & & & & \\
\hline & 1) Shade drying & & & & & & & & & & & & \\
\hline & i) Jute bag & 2 & 6 & 2 & 15 & $\mathrm{~N} / \mathrm{A}$ & 8 & 1 & 24 & 1 & 7 & $\mathrm{~N} / \mathrm{A}$ & 2 \\
\hline & ii) Cloth bag & 2 & 7 & 2 & 16 & $\mathrm{~N} / \mathrm{A}$ & 9 & 1 & 20 & 1 & 9 & $\mathrm{~N} / \mathrm{A}$ & 1 \\
\hline & iii) Polythylene bag & 2 & 1 & 2 & 10 & $\mathrm{~N} / \mathrm{A}$ & 4 & 1 & 10 & 1 & 2 & $\mathrm{~N} / \mathrm{A}$ & $\mathrm{N} / \mathrm{A}$ \\
\hline & 2) Sun Drying & & & & & & & & & & & & \\
\hline & i) Jute bag & 1 & 4 & 2 & 20 & $\mathrm{~N} / \mathrm{A}$ & 10 & $\mathrm{~N} / \mathrm{A}$ & 20 & $\mathrm{~N} / \mathrm{A}$ & 3 & $\mathrm{~N} / \mathrm{A}$ & 1 \\
\hline & ii) Cloth bag & 1 & 4 & 2 & 14 & $\mathrm{~N} / \mathrm{A}$ & 9 & $\mathrm{~N} / \mathrm{A}$ & 24 & $\mathrm{~N} / \mathrm{A}$ & 4 & $\mathrm{~N} / \mathrm{A}$ & 2 \\
\hline & iii) Polythylene bag & $\mathrm{N} / \mathrm{A}$ & $\mathrm{N} / \mathrm{A}$ & 2 & 8 & $\mathrm{~N} / \mathrm{A}$ & 2 & $\mathrm{~N} / \mathrm{A}$ & 14 & $\mathrm{~N} / \mathrm{A}$ & $\mathrm{N} / \mathrm{A}$ & $\mathrm{N} / \mathrm{A}$ & $\mathrm{N} / \mathrm{A}$ \\
\hline 3 & Machine-threshed & & & & & & & & & & & & \\
\hline
\end{tabular}




\begin{tabular}{|c|c|c|c|c|c|c|c|c|c|c|c|c|c|}
\hline & (300 rpm) & & & & & & & & & & & & \\
\hline & 1) Shade drying & & & & & & & & & & & & \\
\hline & i) Jute bag & 1 & 5 & 3 & 18 & 1 & 8 & 1 & 27 & 1 & 9 & $\mathrm{~N} / \mathrm{A}$ & N/A \\
\hline & ii) Cloth bag & 1 & 6 & 3 & 16 & 1 & 5 & 1 & 24 & 1 & 8 & $\mathrm{~N} / \mathrm{A}$ & $\mathrm{N} / \mathrm{A}$ \\
\hline & iii) Polythylene bag & 1 & 1 & 3 & 9 & 1 & 1 & 1 & 12 & 1 & 2 & $\mathrm{~N} / \mathrm{A}$ & N/A \\
\hline & 2) Sun Drying & & & & & & & & & & & & \\
\hline & i) Jute bag & 1 & 5 & 3 & 20 & $\mathrm{~N} / \mathrm{A}$ & 6 & 1 & 24 & $\mathrm{~N} / \mathrm{A}$ & 18 & $\mathrm{~N} / \mathrm{A}$ & $\mathrm{N} / \mathrm{A}$ \\
\hline & ii) Cloth bag & 1 & 5 & 3 & 18 & $\mathrm{~N} / \mathrm{A}$ & 4 & 1 & 14 & $\mathrm{~N} / \mathrm{A}$ & 15 & $\mathrm{~N} / \mathrm{A}$ & N/A \\
\hline & iii) Polythylene bag & $\mathrm{N} / \mathrm{A}$ & 1 & 3 & 10 & $\mathrm{~N} / \mathrm{A}$ & $\mathrm{N} / \mathrm{A}$ & 1 & 8 & $\mathrm{~N} / \mathrm{A}$ & 2 & $\mathrm{~N} / \mathrm{A}$ & N/A \\
\hline 4 & $\begin{array}{l}\text { Machine-threshed } \\
\text { (400 rpm) }\end{array}$ & & & & & & & & & & & & \\
\hline & 1) Shade drying & & & & & & & & & & & & \\
\hline & i) Jute bag & 1 & 6 & 3 & 27 & 1 & 14 & 1 & 24 & 1 & 9 & $\mathrm{~N} / \mathrm{A}$ & 1 \\
\hline & ii) Cloth bag & 1 & 6 & 3 & 19 & 1 & 9 & 1 & 19 & 1 & 8 & $\mathrm{~N} / \mathrm{A}$ & 2 \\
\hline & iii) Polythylene bag & 1 & 1 & 3 & 16 & 1 & 1 & 1 & 2 & 1 & 2 & $\mathrm{~N} / \mathrm{A}$ & $\mathrm{N} / \mathrm{A}$ \\
\hline & 2) Sun Drying & & & & & & & & & & & & \\
\hline & i) Jute bag & 1 & 6 & 2 & 31 & $\mathrm{~N} / \mathrm{A}$ & 19 & $\mathrm{~N} / \mathrm{A}$ & 25 & $\mathrm{~N} / \mathrm{A}$ & 10 & $\mathrm{~N} / \mathrm{A}$ & 2 \\
\hline & ii) Cloth bag & 1 & 5 & 2 & 29 & $\mathrm{~N} / \mathrm{A}$ & 14 & $\mathrm{~N} / \mathrm{A}$ & 19 & $\mathrm{~N} / \mathrm{A}$ & 10 & $\mathrm{~N} / \mathrm{A}$ & 2 \\
\hline & iii) Polythylene bag & 0 & $\mathrm{~N} / \mathrm{A}$ & 2 & 18 & $\mathrm{~N} / \mathrm{A}$ & 5 & $\mathrm{~N} / \mathrm{A}$ & 3 & $\mathrm{~N} / \mathrm{A}$ & 3 & $\mathrm{~N} / \mathrm{A}$ & $\mathrm{N} / \mathrm{A}$ \\
\hline 5 & $\begin{array}{l}\text { Machine-threshed } \\
\text { (500 rpm) }\end{array}$ & & & & & & & & & & & & \\
\hline & 1) Shade drying & & & & & & & & & & & & \\
\hline & i) Jute bag & 1 & 6 & 3 & 27 & 1 & 19 & 1 & 30 & 1 & 15 & $\mathrm{~N} / \mathrm{A}$ & $\mathrm{N} / \mathrm{A}$ \\
\hline & ii) Cloth bag & 1 & 5 & 3 & 21 & 1 & 12 & 1 & 25 & 1 & 10 & $\mathrm{~N} / \mathrm{A}$ & 1 \\
\hline & iii) Polythylene bag & 1 & 2 & 3 & 12 & 1 & 12 & 1 & 15 & 1 & 2 & $\mathrm{~N} / \mathrm{A}$ & N/A \\
\hline & 2) Sun Drying & & & & & & & & & & & & \\
\hline & i) Jute bag & 1 & 5 & 2 & 28 & 1 & 19 & 1 & 34 & $\mathrm{~N} / \mathrm{A}$ & 15 & $\mathrm{~N} / \mathrm{A}$ & 1 \\
\hline & ii) Cloth bag & 1 & 4 & 2 & 20 & 1 & 12 & 1 & 29 & $\mathrm{~N} / \mathrm{A}$ & 9 & $\mathrm{~N} / \mathrm{A}$ & 2 \\
\hline & iii) Polythylene bag & $\mathrm{N} / \mathrm{A}$ & $\mathrm{N} / \mathrm{A}$ & 2 & 10 & 1 & 7 & 1 & 11 & $\mathrm{~N} / \mathrm{A}$ & 2 & $\mathrm{~N} / \mathrm{A}$ & N/A \\
\hline & Total & 29 & 106 & 65 & 318 & 15 & 150 & 21 & 424 & 12 & 155 & 0 & 20 \\
\hline
\end{tabular}

